\title{
Apa Makna Karir Bagimu?: Pemaknaan Kata Karir pada Mahasiswa Tingkat Akhir Mahasiswa Universitas Lampung
}

\author{
Moch Johan Pratama \\ FKIP Universitas Lampung, J1. Prof. Dr. Soemantri Brojonegoro No. 1 Bandar Lampung \\ *Corresponding e-mail: mochjohanp@gmail.com
}

Received: 5 Oktober $2017 \quad$ Accepted: 1 November $2017 \quad$ Published: November 2017

Abstract: What is the meaning of Career according to you?: The Meaning of Career on the Final Year Students of Lampung University. This paper investigated the phenomena of Lampung University students' lack interest to engage in career guidance program (especially career plan topic) through survey related to the quality of Lampung University final year students' understanding about the meaning of words "career". This is a survey research which invloved 285 respondents. The results showed that 74\% of subjects have low understanding about the meaning of word "career", they only see career as work. Almost a half of the subjects (45\%) make the income aspect as priority consideration in choosing a job compared to the talent and interest aspect and career path aspect.

Keywords: career education, career development program, theory of planned behavior

Abstrak: Apa Makna Karir Bagimu?: Pemaknaan Kata Karir pada Mahasiswa Tingkat Akhir Mahasiswa Universitas Lampung. Penelitian ini menginvestigasi fenomena rendahnya minat mahasiswa Universitas Lampung untuk mengikuti program pembinaan karir (perencanaan karir) melalui survei mengenai pemahaman mahasiswa tingkat akhir Universitas Lampung terhadap makna kata karir. Penelitian survei ini melibatkan 285 responden. Hasil penelitian menunjukkan bahwa 74\% subjek memiliki pemahaman makna karir yang rendah, yaitu hanya sebatas "bekerja". Hampir sebagian subjek (45\%) menjadikan aspek penghasilan sebagai prioritas pertimbangan dalam memilih pekerjaan, dibanding aspek kesesuaian bakat dan minat dan aspek jenjang karir.

Kata kunci: pendidikan karir, program pengembangan karir, theory of planned behavior

\section{PENDAHULUAN}

Super (1953) melalui Career Pattern Theory (CPT) menjelaskan bahwa untuk mencapai kematangan karir, setiap individu harus menyelesaikan tugas karir pada setiap tahapan perkembangannya. Berdasarkan CPT, mahasiswa berada pada tahapan eksplorasi, lebih spesifiknya tahap transisi dimana individu memiliki tugas untuk mulai membuat pertimbangan karir yang realistis berdasarkan kemampuan individu untuk mengimplementasikan konsep diri pada suatu bidang pekerjaan. Pertimbangan karir yang realistis dapat dicapai melalui pengalaman mahasiswa yang mulai mengenal pasar kerja dan 
mengikuti pelatihan yang mengasah profesionalitas.

Career Pattern Theory (CPT) menjadi dasar pikir UPT Pengembangan Karir dan Kewirausahaan (UPT. PKK) Universitas Lampung dalam merancang program pembinaan karir bagi mahasiswa. Program pembinaan karir di desain untuk membantu mahasiswa dalam melaksanakan tugas perkembangan karir, tetapi pada pelaksanaannya program tersebut kurang mendapatkan respon baik dari mahasiswa. Divisi Pembinaan dan Konsultasi Karir, UPT. PKK Universitas Lampung (2016) melaporkan rendahnya rendahnya jumlah peserta yang mendaftarkan diri pada program pembinaan karir (perencanaan karir). Kondisi ini kemudian dijajaki dengan melakukan focus group discussion kepada tingkat akhir Universitas Lampung terkait topik minat mahasiswa untuk mengikuti program pembinaan karir. Hasil yang didapatkan adalah rendahnya intensi mahasiswa tingkat akhir untuk mengikuti program pembinaan karir, mereka kurang memahami apa manfaat kegiatan tersebut bagi diri mereka.

Rendahnya intensi mahasiswa untuk mengikuti program pembinaan karir dapat dikaji melalui Theory of Planned Behavior (TPB) yang dikemukakan oleh Ajzen (1991). TPB menjelaskan bahwa intensi (niat) merupakan prediktor perilaku seorang individu. Lebih lanjut dijelaskan bahwa intensi diawali oleh pemahaman yang tepat akan manfaat dari melakukan perilaku tersebut bagi diri individu. Pemahaman tersebut yang kemudian akan membentuk keyaninan dan kemudian sikap positif terhadap sebuah perilaku.

Penelitian ini bertujuan untuk menginvestigasi kondisi pemahaman mahasiswa tingkat akhir Universitas Lampung terhadap makna dari kata karir sebagai dasar pembentukan intensi perilaku mahasiswa untuk mengikuti program pembinaan karir yang dilaksanakan oleh UPT. PKK Universitas Lampung.

\section{METODE}

Jenis penelitian dalam penelitian ini yaitu penelitian survei yang mengacu pada Fink (2008), di mana survei merupakan sistem pengumpulan informasi valid dari orang banyak dengan tujuan untuk membandingkan, menggambarkan atau menjelaskan pengetahuan, sikap serta perilaku mereka. Pada konteks penelitian ini survei bertujuan untuk mengetahui pemahaman mahasiswa tingkat akhir unila akan makna dari kata karir. Survei disampaikan secara daring dengan menggunakan bantuan aplikasigoogle form kepada 285 mahasiswa tingkat akhir (semester 4 ->8) Universitas Lampung yang telah tergabung sebagai member di UPT PKK Universitas Lampung. Terdapat dua pertanyaan yang dianalisis secara spesifik pada survei ini, yaitu: 1) Secara singkat, tolong tuliskan definisi dari kata karir yang kamu pahami; 2) Jika kelak tiba saatnya untuk memilih sebuah pekerjaan, aspek apa saja yang akan kamu pertimbangkan? Tuliskan minimal 3 aspek!

Analisis data untuk pertanyaan pertama adalah mengkonstruk definisi operasional dari kata karir sebagai standarisasi untuk mengkategorikan jawaban yang diberikan oleh subjek. Definisi operasional kata karir merujuk pada: Kamus Oxford versi daring (2017), Kamus Besar Bahasa Indonesia versi daring (2017), Kamus Merriam Webster versi daring (2017) dan Super (1980). Hasil analisis dari berbagai sumber tersebut menyiratkan benang merah dari makna kata karir, yaitu sebuah pekerjaan/jabatan yang dapat membawa peluang kemajuan dan pengembangan dalam berbagai aspek kehidupan. Berdasarkan definisi tersebut ditentukanlah dua kata kunci utama dalam memaknai kata karir, yaitu pekerjaan dan kemajuan. Kedua kata tersebut menjadi filter dalam mengkategorikan jawaban yang diberikan subjek pada pertanyaan pertama. Tabel 1 akan menjelaskan lebih lanjut tentang filter tersebut. 
Tabel 1. Kata Kunci untuk Memfilter Jawaban Subjek

\begin{tabular}{|c|c|}
\hline Kata Kunci & Persamaan konteks \\
\hline Pekerjaaan & $\begin{array}{l}\text { Jabatan, Profesi, status, } \\
\text { usaha, produktifitas, sepak } \\
\text { terjang, kiprah, posisi, } \\
\text { hobi }\end{array}$ \\
\hline Kemajuan & $\begin{array}{l}\text { Perkembangan, } \\
\text { Peningkatan, perluasan, } \\
\text { berjenjang, berkelanjutan, } \\
\text { pencapaian, } \\
\text { berkesinambungan }\end{array}$ \\
\hline
\end{tabular}

Tahapan selanjutnya adalah kategorisasi jawaban subjek berdasarkan filter yang telah ditetapkan. Terdapat tiga kategori jawaban yang akan dijelaskan pada Tabel 2 .

Tabel 2. Kategorisasi Jawaban Subjek

\begin{tabular}{cc}
\hline Kriteria & Deskripsi \\
\hline 0 & $\begin{array}{c}\text { Jawaban tidak mengandung } \\
\text { kata kunci dari definisi karir }\end{array}$ \\
\hline 1 & $\begin{array}{c}\text { Jawaban hanya mengandung } \\
\text { satu kata kunci karir }\end{array}$ \\
\hline 2 & $\begin{array}{c}\text { Jawaban mengandung kata } \\
\text { kunci karir secara lengkap }\end{array}$ \\
\hline
\end{tabular}

Analisa data untuk jawaban pertanyaan kedua dilakukan dengan mengambil jawaban pertama dari minimal tiga aspek pertimbangan yang diberikan oleh subjek, dan kemudian mengkategorikannya dengan jawaban yang memiliki konteks serupa.

\section{HASIL DAN PEMBAHASAN}

Berdasarkan hasil kategorisasi jawaban atas pertanyaan pertama ditemukan bahwa 210 subjek memberikan jawaban pada kriteria 1, kemudian 39 subjek berada pada kriteria 0 dan hanya 36 orang dengan jawaban yang benar. Mayoritas Subjek beradapada kriteria 1, mereka memaknai karir dengan konteks pekerjaan (bekerja,jabatan, profesi dan tugas). Subjek pada kriteria 0 memberikan jawaban yang tidak sesuai konteks kata kunci seperti: gaji, penghasilan, hidup, harapan dan jurusan perkuliahan. Persentase jawaban subjek dapat dilihat pada Gambar 1.

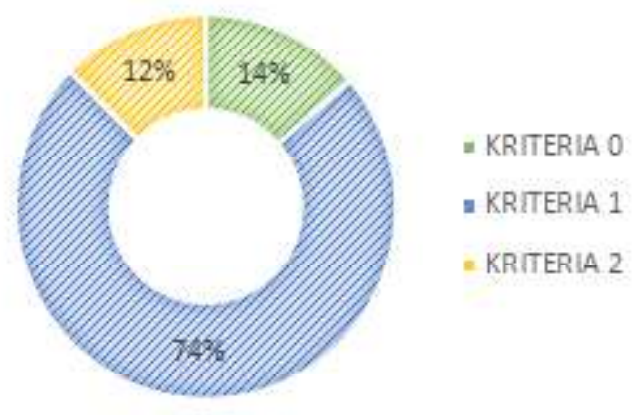

\section{Gambar 1. Persentase Hasil Pertanyaan 1}

Analisis hasil pertanyaan kedua memunculkan 5 kelompok jawaban, yaitu aspek penghasilan sebanyak 127 subjek (gaji, ekonomi, dan kemakmuran), aspek lingkungan 72 subjek (lokasi, keamanan, jarak tempuh, keadaan sosial), aspek kepribadian sebanyak 60 subjek (bakat, minat, passion, hobi), aspek religiusitas sebanyak 16 subjek (tanggung jawab kerja, kebermanfaatan, ridho Illahi) dan aspek jenjang karir sebanyak 10 subjek (prospek, peluang, promosi). Persentase jawaban subjek dapat dilihat nada Gambar 2.

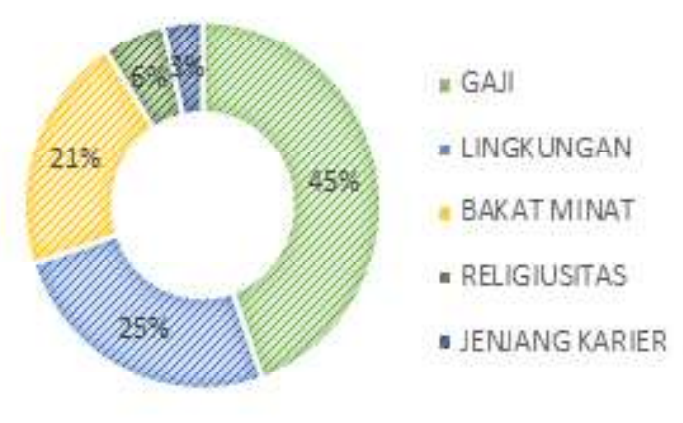

Gambar 2. Persentase Hasil Pertanyaan 2 
Temuan signifikan dari investigasi ini adalah mayoritas subjek (74\%) masih memaknai karir dengan sempit sebatas sebuah pekerjaan dan bahkan sebanyak 39 subjek (14\%) masih salah kaprah. Dampak pemaknaan karir yang tidak holistik dapat dicermati dari jawaban pertanyaan 2, dimana mayoritas subjek (45\%) menjadikan aspek penghasilan prioritas pertimbangan dalam memilih pekerjaan. Padahal jika ditilik dari makna karir secara holistik, dimana karir adalah sebuah perkerjaan yang dapat membawa kemajuan di segala aspek kehidupan, maka idealnya dalam memilih pekerjaan seorang individu menjadikan aspek kepribadian (bakat, minat, passion) sebagai pertimbangan utama.

Temuan tersebut menegaskan sudut pandang Ajzein (1991) melalui Theory of Planned Behavior dimana pemahaman akan membentuk sikap yang pada akhirnya menjadi intensi perilaku sebagai prediktor aktualisasi sebuah perilaku. Temuan ini kemudian dapat menjelaskan bahwa salah satu penyebab rendahnya intensi mahasiswa untuk mengikuti program pembinaan karir yang dilakukan oleh UPT. PKK Universitas Lampung adalah pemahaman sempit akan makna kata karir.

Data yang didapatkan dari analisis pertanyaan pertama dan kedua menunjukkan bahwa mayoritas subjek memaknai karir sebatas sebuah pekerjaan untuk mendapatkan penghasilan, sehingga mereka cenderung akan mempersiapkan diri hanya untuk bekerja bukan berkarir. Hal ini dapat disintesakan dengan pengalaman implementasi program di UPT. PKK Universitas Lampung, dimana program pembinaan karir yang paling diminati adalah persiapan menghadapi proses rekruitmen kerja yang notabene secara konkret untuk mengajarkan tentang keterampilan memasuki dunia kerja, sedangkan program-program dengan konteks perencanaan karir seperti ; topik life plan dan soft skills sangat rendah peminatnya.
Berdasarkan temuan diatas, maka penelitian mendatang akan diarahkan pada konstruksi program dan strategi yang secara efektif dapat meningkatkan kualitas pemahaman mahasiswa Universitas Lampung akan makna karir. Meningkatnya kualitas pemahaman diharapkan dapat membuka kesadaran mahasiswa bahwa perencanaan karir sedini mungkin merupakan sebuah kebutuhan dan pada akhirnya terciptalah supply-demand terhadap program pengembangan karir yang ditawarkan oleh UPT. PKK Universitas Lampung

\section{SIMPULAN}

Berdasarkan Theory of Planned Behavior (Ajzein, 1991) kualitas pemahaman adalah salah satu aspek yang mendeterminasikan perubahan perilaku individu. Analisis data menyatakan bahwa 74\% subjek masih memaknai karir dengan sempit, yaitu hanya sebatas pekerjaan, Dampaknya dapat dicermati dari jawaban pertanyaan 2, dimana mayoritas subjek (45\%) menjadikan aspek penghasilan prioritas pertimbangan dalam memilih pekerjaan. Temuan ini dapat menjelaskan fenomena rendahnya minat mahasiswa untukmengikuti program perencanaan karir dibandingkan program persiapan memasuki dunia kerja pada UPT. PKK Universitas Lampung.

\section{DAFTAR RUJUKAN}

Ajzen, I. 1991. The Theory of Planned Behavior. Organizational Behavior and Human Decision Process. 50:179-211. doi: 10.1016/0749-5978(91)90020-T

Fink, A. 2008. How to Conduct Surveis, 3rd edn. New Delhi: Sage. doi: 10.1016/ j.lisr.2006.05.002

Super, D. E. 1953. A Theory of Vocational Development 1. American Psychologist. 8:185-190. doi: 10.1037/h0056046. 
Super, D. E. 1980. A Life-Span, Life-Space Approach to Career Development. Journal of Vocational Behavior. 16: 282-298. doi: 10.1016/0001-8791(80)90056-1

English Oxford Living Dictionary. 2017, August. Definition of career in English. https:// en.oxforddictionaries.com/definition/career Kamus Besar Bahasa Indonesia. 2017, Agustus. Arti kata karir dalam bahasa indonesia. diakses dari https://kbbi.web.id/karir Merriam Webster Dictionary. 2017, August. Definition of career diakses dari https:// www.merriam-webster.com/dictionary/ career

Tim Penyusun. 2016. Laporan Kegiatan Tahunan. Unit Pelayanan Teknis Pengembangan Karir dan Kewirausahaan (UPT. PKK) Universitas Lampung. Bandar Lampung. 